\title{
電子分光法による表面定量分析法の進歩
}

\author{
吉 原 一 紘 \\ 金属材料技術研究所 3305 つくば市千現 1-2-1
}

(1994年 8 月 2 日受理)

\section{The Progress in Quantitative Surface Analysis with Electron Spectroscopy}

\author{
Kazuhiro YoshiHaRA \\ National Research Institute for Metals \\ 1-2-1, Sengen, Tsukuba 305
}

(Received August 2, 1994)

\begin{abstract}
電子分光を用いる表面分析法が実用化されて，広く市場に出回りはじめてからすでに20年以上が経過してい る。その間に，電子分光法に対するユーザーの認識は「定性分析法」から「定量分析法」へと撖しいものになっ てきた。1982年にVAMAS プロジェクトが発足して以来，ハードウェアの面では，強度軸，エネルギー軸の較 正法に関して，いくつかの提案がなされたし，またソフトウェアの面でも，バックグランド差し引き法や脱出 深さ計算法などに関して精力的な研究がなされた。さらに，スペクトルデータの記録方式の統一基準が提案さ れ，各メーカーのスペクトルデータをこの方式に変換し，デー夕処理法を共通で評価するためのソフトウェア も開発され，スペクトルデータベースを構築する目途が立つようになった。これらを受けて，1991年より表面 分析の国際規格化を図るために ISO/TC201 委員会がわが国の提案を基にして設立された。このように，電子分 光法による表面組成の定量精度の向上を目指した研究はこの15年で大きく進歩した。
\end{abstract}

\section{1.は じめに}

表面分析に関しては, 日本表面科学会はこれまでに 「表面科学基礎講座」のテーマとして創立当時から積極 的に取り組み，この分野において大きな貢献をしてき た。小生もごく初期からこの講座の企画に携わる機会が 与えられたため, 自分自身がこの講座によって育てられ たという思いがある。また，表面科学誌にも，表面分析 関連の論文や解説は数多く掲載されている。いま手元に ある第 10 巻 10 号（日本表面科学会創立 10 周年記念特集 号）を読むと，表面界面分析は9人の先生方が執筆され ており, 特に小生がここで取り上げようという電子分光 の分野では東工大宮崎先生がXPS と UPS ${ }^{1)}$, 鳥取大徳高 先生が $\mathrm{AES}^{2)}$ についてその進歩と展望を詳しくまとめら れている。

表面分析の分野では，「よりミクロに」と「より正確 に」を目標にして，これまでにハードウェアとソフト ウェアの両面で大きく進歩してきた。ここでは, 微小領 域分析に関する進歩に関して述べることは別な機会にゆ ずるとして, 電子分光を用いた表面組成定量法の向上を
目指した研究を紹介してみたい。

電子分光を用いる表面分析法が実用化されて, 広く市 場に出回りはじめてからすでに 20 年以上が経過してい る。その間に, 電子分光法に対するユーザーの認識は 「定性分析法」から「定量分析法」へと厳しいものに なってきた。このようなユーザーの要求に対して, メー カーも装置の性能の向上, ソフトウェアの進歩などによ り対応し, 現在ではューザーがコンピューターのキー ボードを吒けば定量值が求められるようになってきた。 しかし, 電子分光法は光や電子と固体の複雑な相互作用 の基に発生した電子のエネルギーと数を複雑なエネル ギー透過率をもつエネルギー分光器で分光して, 複雑な 計数特性をもつ電子増倍管や計数器で数えるという過程 を経てスペクトルを取得し，複雑なデー夕処理により ピーク部分を抽出して解析する方法であり，ユーザーも 正確な定量分析を行うためにはハードウェアおよびソフ トウェアに関する知識が要求されることになる。もちろ んどのような分析法でも専門知識なしに分析すれば誤っ た情報を得る可能性が生じるのは当然である。しかし， 表面分析法がさらに広く使われていくためには, 複雑な 
知識を駆使して分析しなくても, 一定精度の分析ができ るようにする必要がある。このために現在, VAMAS や ISO/TC201 という, 表面分析の標準化に関する国際 共同プロジェクトが実行されている。

\section{VAMASプロジェクト}

1982年 6 月のヴェルサイユサミットにおいて, 先端材 料に関する標準的試験評価法の確立に関して国際共同研 究を行うことが決められた。VAMAS とはVersailles Project on Advanced Materials and Standards の略語で ある。VAMAS プロジェクトは15の技術委員会に分かれ ており, その中の一つが表面化学分析 (Surface Chemical Analysis) で, 議長は英国 NPL の Seah 博士が務めて いる。オージェ電子分光法 (AES), $X$ 線光電子分光法 (XPS) などの電子分光法や 2 次イオン質量分析法 (SIMS) などの表面化学分析法に関しては, これまで, 得られた デー夕に互換性がなく, データの信頼性に対して不満が あったため, このプロジェクトが発足した際に, 技術委 員会の一つとして，当初から組み入れられた。

VAMAS プロジェクトで提唱された表面化学分析に関 する活動を行うために，わが国では約900研究機関から なる研究会が組織された。この研究会は, VAMAS プロ ジェクトとして提案されている表面分析法の信頼性の向 上に関する国際共同研究に協力すると同時に，わが国が リーダーシップをとった共同研究を推進することを目的 として活動しており，これまでに， $\mathrm{Au}-\mathrm{Cu}$ 合金, $\mathrm{Co}-\mathrm{Ni}$ 合金をラウンドロビン試料とした, AES, XPS の定量精 度の把握に関する国際共同研究を実行してきた3 5)。ま た,このような共同研究以外にも, 表面化学分析法の 精度向上のために, 名工大後藤敬典教授らによる標準 CMA 分光器の試作 ${ }^{6,7)}$, 標準チャンネルトロンの試作 ${ }^{8)}$ などを行うと共に, バックグランドの差し引き方法, 固 体内での電子の挙動などに関しての勉強会9)開催し, 分 光器特性をどのように把握し, 補正するか, 正しいスペ クトルとはどのようなものか, 異なった機種間で取得さ れたスペクトルデータをどのように統一的に評価する か, また, スペクトルのデータベースをどのように作っ ていくかということに関して, 研究活動が行われてきた。

\section{3. 分光器の特性}

定量分析精度を向上させるための基本は, 試料から放 出されたスペクトルをいかに正しく観測し, 評価するか ということである。しかし, 実際に装置から得られるス ペクトルは, 装置の特性により歪み, エネルギー値, 強 度, 分解能が影響を受ける。したがって, その歪みをど のように補正するかということが, 実際の測定上では重
要なこととなる。

\section{1 エネルギー軸の較正}

われわれが観測する電子のエネルギーは分光器の真空 準位から測定した運動エネルギーを観測することにな る。しかし, 分光器の真空準位は装置ごとに異なるため に，較正用のエネルギー基準としては，Fermi 基準をと る必要がある。

AES の場合は, 電子の運動エネルギーをそのまま報 告することになるため, 報告された值は分光器の work functionの影響を受けたものとなる。したがって，各自 がそれぞれ分光器の work function を求めない限り, ピークの位置データの相互比較は困難となるが, 分光器 の work functionを正確に求めることは容易ではない。

これまでに, AES ピークの基準值としては, Seah, Smith and Anthony から報告された Fermi 準位を基準 とした值 ${ }^{10}$ が一応の基準として参照されている。この基 準值を使用して, 各自の分光器の work functionの補正 値を簡便に計算する方法が最近提案された ${ }^{11)}$ 。この方 法は, 各自が測定した $\mathrm{Cu}, \mathrm{Ag}, \mathrm{Au}$ のピーク位置（真空 準位を基準にして）と基準值との差を offset function と 定義し, 補正に使用する方法である。本来はこの補正値 は分光器の work function と一致するはずであるが, 実 際にはこの関数はディジタルボルトメーターの䛊差など も加わって, エネルギー依存性をもち, work function とは必ずしも一致しない。

求めた offset function を電子の運動エネルギーの 1 次 式で記録しておくと，各自のデータを Fermi レベルを基 準とした值に変換できる。この関数の有効性をラウンド ロビンにより調べてみると，ラウンドロビンに参加した 研究機関のエネルギー値のばらつきは offset func-tion を用いることにより 1/6〜1/3 程度に縮小されることがわ かった11)。

しかし，基準值として Seahらが提案した価が真に正 しいかどうかは検証されていない。2 節で述べた後藤敬 典教授の分光器は機械的に検証された分光器であるた め, この分光器から得られたエネルギー値も今後基準值 としての候補となろう。

XPS の場合, 観測した運動エネルギーは束縛エネル ギーに変換して報告する。この場合, 分光器のエネル ギー軸の“0”を Fermi 基準にとることが通常であるた めに, Fermi エッジがはっきり出る物質（たとえば Ni）の Fermi エッジを“0”として原点を決め, つぎ に, $\mathrm{Cu}, \mathrm{Ag}, \mathrm{Au}$ の束縛エネルギーの基準データ12)を参 照し, AES と同様に offset function としてエネルギー 軸を補正し，記録しておけばよい。

\section{2 強度の較正}


分光器を経たスペクトル強度は, 次式で与えられる測 定信号度 $I(E)$ として観測される ${ }^{13)}$ 。

$$
I(E)=H(E) T(E) D(E) F(E) n(E)
$$

ここに, $E$ はエネルギー, $H(E)$ は残留磁界や分光器 内部で発生した電子がスペクトルに及斿す撖乱の効果, $T(E)$ は分光器の透過関数, $D(E)$ は検出器 (2次電子 増倍管) の効率, $F(E)$ は信号検出システムにおけるエ ネルギーに依存した伝達効率を表わしている。 $n(E)$ が 測定すべき試料から放出される信号電子のスペクトルで ある。表面分析法を標準化するためには, これらスペク トル強度に影響を与える因子を正確に定義し， $I(E)$ か ら $n(E)$ を推定することから始めていかなくてはならな い。ただし, $n(E)$ は, 検出角, 1 次電子の入射角にも 依存することに注意しなければならない。これまでに， 装置特性をどのように記述するかということについては いくつかの報告が出されてきた14 16)。それぞれの影響を 簡単に解説する。

\section{(1) 磁場 $(H(E))$ の影響}

スペクトル形状のばらつきの一つの原因は磁場の影響 である。特に，スペクトルの低エネルギー側は大きな影 響を受ける。図1に1次電子ビームを絞る方式が, 静電 レンズ方式と電磁レンズ方式の場合とで, $\mathrm{Ag}$ から得ら れるスペクトルが数十 $\mathrm{eV}$ 以下の領域では大きく変わる 例を示す。

\section{(2) 分光器の透過関数 $(T(E))$ の影響}

分光器の透過特性は同じタイプの分光器であってもそ れぞれ大きく異なっている。特にXPS の場合に用いら れる半球型の分光器にはインプットレンズが付け加わっ ているために, 複雑な透過特性を示す。図 2 に $\mathrm{Ag}$ の XPS スペクトルを異なるメーカーの半球型の分光器で取 得したものを示す。

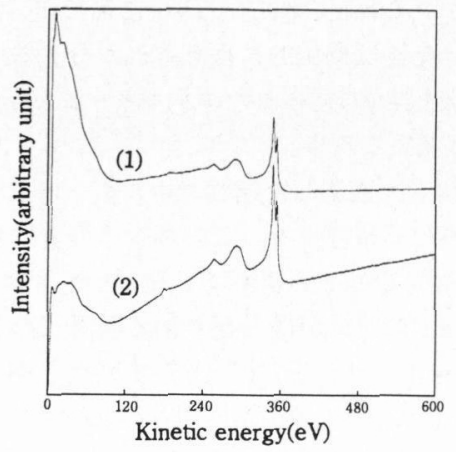

図 11 次電子ビームを絞る方式を, 静電レンズ 方式 (1) と電磁レンズ方式 (2)としたとき に得られた, $\mathrm{Ag}$ の AESスペクトルの例

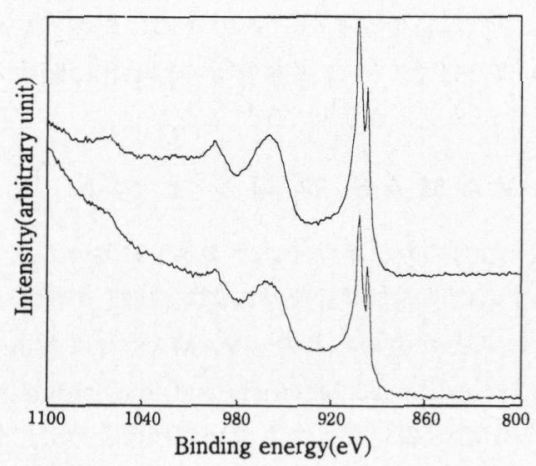

図 2 異なるメーカーの分光器で AgのXPSスペ クトルを測定したときに，インプットレン ズの特性によりスペクトル形状が異なる例

\section{( 3 ) 検出器の効率 $(D(E))$ の影響}

図3は市販の電子増倍管 $(\mathrm{EM})$ のもつ電流増幅特性を, EMに対する電子の入射エネルギーの関数として示したも のである ${ }^{17)}$ 。電子分光では一般に $2000 \mathrm{eV}$ 程度以下の運 動エネルギーの電子を検出対象とするため, 図3の左半分 の特性が実際には意味がある。低エネルギー側の効率の 低下とともに，タイプによっては高エネルギー側でも効 率の低下が著しいことに注意すべきである。

\section{(4) 伝達効率 $(F(E))$ の影響}

検出にパルスカウント法を使う場合には，パルス検 出システムの数え落としがデー夕の伝達効率に影響を 及ほす。伝達効率は装置によって異なっており，各自 の装置の不感時間を正確に調べて, 全スペクトル領域 において, 計数值の飽和がおきないようにしなくては ならない。

したがって，各自のスペクトルデータを互いに比較す

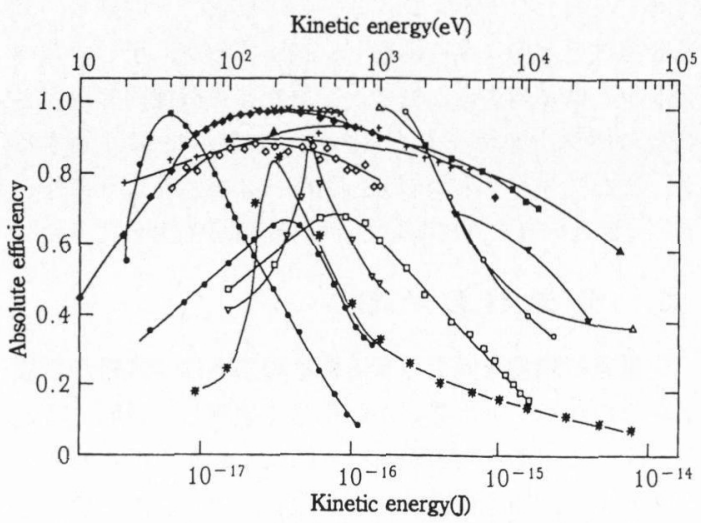

図 3 各種メーカーの分析装置の電子増倍管のもつ電流 増幅特性と電子の入射エネルギーの関係 ${ }^{17}$ ) 


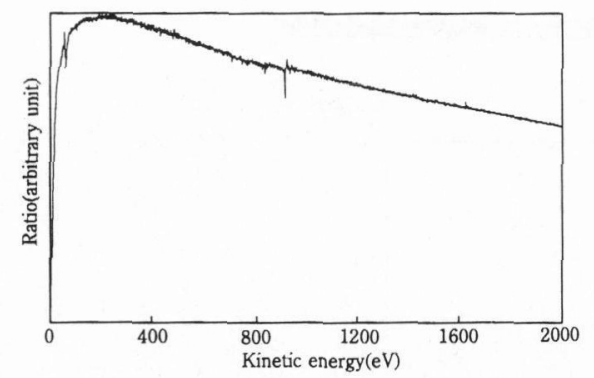

図 4 市販の装置(Double-Pass CMA) で取得された $\mathrm{Cu}$ のスペクトルを後藤教授のスペクトルで 割り算した結果

るためには分光器の強度のエネルギー依存性を求めてお く必要がある。しかし通常，（１）式で述べた各因子を 正確に求めることは容易ではない。そこで, AES と XPS の “標準”スペクトルを決めておき，各自が取得したス ペクトルをその"標準" スペクトルで割り算し，その結 果を強度補正関数として登録しておくという方法が提案 された17)。わが国としては，AESについては，“標準” スペクトルとして, 名工大後藤敬典教授の分光装置〉に より取得した $\mathrm{Au}, \mathrm{Ag}, \mathrm{Cu}$ スペクトルが, また, XPS “標準”スペクトルとしては，金材技研で Double-Pass CMA により取得した $\mathrm{Au}, \mathrm{Cu}$ スペクトルを“標準” ス ペクトルとしている。これは, Double-Pass CMA には インプットレンズがないために，透過特性が単純であ り，“標準”スペクトルを取得するには適した装置であ ると思われるからである。これらのスペクトルを基準と して強度補正関数を求めようという試みがラウンドロビ ン試験を通じて行われた18)。

図 4 に市販の装置 (Double-Pass CMA) で取得された $\mathrm{Cu}$ のスペクトルを後藤教授のスペクトルで割り算した 結果を表示する。この曲線の形状はどの分光器から得ら れたものもほぼ同一の形をしており ${ }^{18)}$ ここの曲線はチャ ンネルトロンのエネルギー特性を示している。

\section{3 分解能の較正}

エネルギー軸と強度軸を較正すると, つぎに考慮しな ければならないことは, ピークの分解能である。

分解能は Gaussian 型の分解能関数を仮定すると ( 2 ) 式のように表わすことができる。

$$
\Delta E^{2}=\Delta E_{o}^{2}+\Delta E_{l}^{2}+\Delta E_{a}^{2}
$$

ここで,

$\Delta E \quad$ : 観測されたピークの分解能

$\Delta E_{O}:$ : ピークの固有幅

$\Delta E_{l}$ : 励起線源の幅（XPS の場合のみ問題となる）
$\Delta E_{a}:$ 分光器の分解能

いま, 分解能関数が $h(\tau)$ として定義されると, 観 測されるスペクトル $(I(E))$ は分解能関数と真のスペク トル $(n(E))$ とのコンボリューション積分により，（3) 式のように表わすことができる。

$$
I(E)=\int h(\tau) n(E-\tau) d \tau
$$

となる。

ただし，観測されたピークにはこのほかに，バックグラ ンドや分光器のノイズが乗ってくる。真のピークを得るた めには，さらにそれらを除去する手続きが必要である。

\section{4. スペクトル強度の評価}

\section{1 バックグランドの評価}

3 節で述べたように，われわれは分光器のハードウェ アとしての特性を評価するための研究を進めてきた。し かし，たとえ，正確に試料から発生したスペクトル強度 を測定したとしても，そのスペクトルが定量分析に有効 な情報だけを有しているわけではない。すなわち，ある 特定の内殼から発生した光電子やオージェ電子の量をす ベて計測できれば定性分析という観点からは問題はない が，実際にはそれらの電子の一部分は固体内で非弾性散 乱を受けてエネルギーを失い, どの内殼から発生した電 子であるかは区別できなくなってしまう。そこで，それ らの非弾性散乱電子の寄与をスペクトルから差し引くこ とにより，エネルギーを失っていない電子のスペクトル を推定し，エネルギー值やカウント数を求めて定性分析 や定量分析を実行する。この作業をわれわれはバックグ ランド差し引きと称している。

これまでに，いくつかのバックグランドを差し引く方 法が提案されてきた ${ }^{19)}$ 。これらの中で, 現在最もバック グランドを広い範囲で差し引くのに適しているとされて いるのは Tougaard が提案した方法である ${ }^{20,21) 。 こ の 万 ~}$ 法は，電子が固体内でどれだけエネルギーを失うかを表 わす沉用関数を仮定してバックグランドを差し引くもの で，比較的容易に短時間（コンピューター上で）でバッ クグランドを差し引くことができる。なお,この方法を さらに改良した方法も提案されている22)。

\section{2 脱出深さの評価}

定量精度を上げるために考慮すべき重要な点のもうひ とつは，電子の固体からの脱出深さに関する情報を決定 することである。これまでに減衰長さについては，経験 式として Seah-Denchの式 ${ }^{23)}$, Tokutaka-Nishimori-

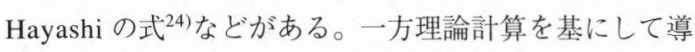
いているのが Tanuma-Powell-Penn の式25,26)で, Tanuma らは実験的に求められた光学データを用いてそれらの物 


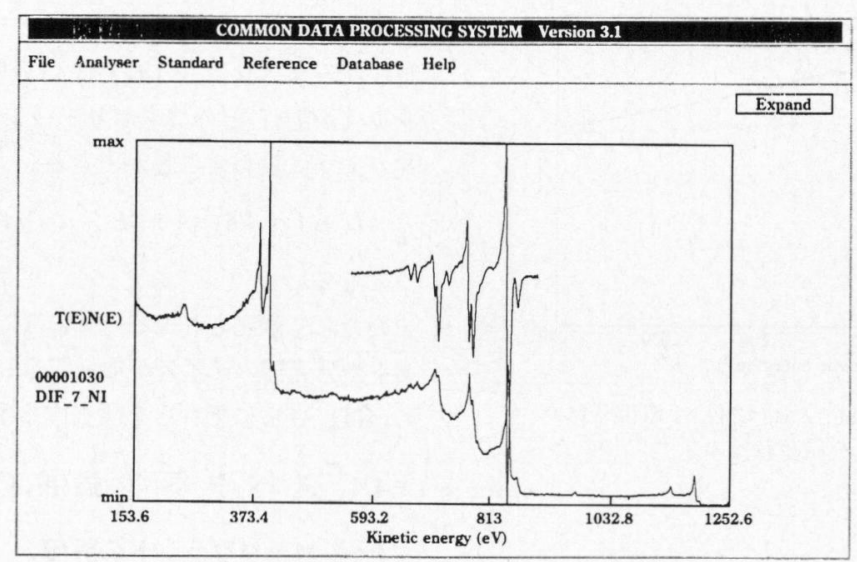

図 5 異なるメーカーの分光器から取得された, NiのAESとXPSスペクトル のCommon Data Processing System Version 3.1の同時表示画面

質のエネルギー損失関数を決定し，これにより非弾性平 均自由行程を求めた。これらの式のどれが, 脱出深さを よりよく評価をしているかを決めることは難しい27)。し かし，現実には信頼性のおける実測值が少ないというこ とから, Tanumaらの非弾性平均自由行程の計算式から 求めるのが妥当であろう。

\section{5. 共通データ処理環境}

最近の分析装置はすべてコンピューターが付置されて おり，独自のスペクトル解析ができるようになってい る。しかし, 登録されたスペクトル解析法は, その妥当 性までは保証されているわけではない。また, 必ずしも 市販の分析装置は標準的なスペクトルデー夕を取得する ようには考えられていない。

したがって,スペクトルデータの記録方式を統一し， 異なった装置から得られたスペクトルでも同一のパーソ ナルコンピューターで取り扱えるようなシステムを構築 することができれば, スペクトル解析法の標準化や，ス ペクトルデータベースの構築が可能となる。

VAMAS-SCA研究会では, 統一したデータ構造で, スペクトルを記録し，それを互いに転送しようというこ とを目指して, デー夕転送用統一フォーマットを作成し た28)。これを受けて, 異なった表面化学分析機種から得 られたスペクトルデータでも共通でデー夕処理できるソ フトウェア (Common Data Processing System)を作製 することを目的としたプロジェクトが1990年より開始 された ${ }^{29)}$ ここのプロジェクトの目的は, (1)各メーカーの 装置から出力されるスペクトルデー夕を自動的に VAMAS Surface Chemical Analysis Standard Data
Transfer Format ${ }^{28)}$ に変換すること, (2)今まで多くの研 究者から提案されたデー夕処理法を検証するための共通 のコンピューター環境を提供すること, (3)各人が使用し ている分光器の特性を決定する指針を与えること, 掠よ び(4)スペクトルのデータベースを作成すること，を目的 としたソフトウェアを作成することである。

Common Data Processing Systemは, IBM-PCまた は NEC-PC を対象とし, OS は Windows 3.1 を用いて いる ${ }^{30)}$ 。現在, 各社の装置からのデー夕を共通のデー夕 構造に変換し, IBM-PCまたは NEC-PC 上でデー夕処 理や装置の較正ができるようになっている。さらに, Common Data Processing System には, スペクトルデー タベースが組込まれており, 現在, VAMAS-SCA 研究 会の有志の方々の約70元素, 450本のスペクトルが登録 されている。また，2章で述べた後藤教授が試作した標 準分光器で得られたスペクトルやDouble-Pass CMA で 取得されたスペクトルも組込まれており, 各自の分光器 特性の把握のために使用できるようになっている。図 5 に，異なった機関から得られたXPSのスペクトルと AES のスペクトルを同時表示させた画面を示す。この ように異なった装置から得られたスペクトルデー夕も比 較することができるようになり, 今後スペクトルのデー タベースを構築することが可能となった。

\section{6. 表面化学分析法の国際標準化の動き}

1982年以降のこのような表面化学組成定量分析精度 の向上を目指した研究活動を通して, 表面分析手法も共 通で規格化できるという認識が醹成され, 国際的な標準 規格をこの分野でも作ろうではないかという気運が高ま 
り，わが国が提唱して，1991年10月に ISO に表面化学分 析の技術委員会(ISO/TC201)が設置された。ISO/TC201委 員会の幹事国は日本，議長は米国 NIST の Powell 博士と いう体制でスタートした。この委員会の中には，AES， XPS, SIMS, GDOS, TXRF などの代表的な表面化学分 析法別に小委員会が設けられているほか，共通の話題で ある，用語の定義，デー夕処理法，などに関する小委員 会も併せて設けられている。現在, 各国からいくつかの 規格案が提案され，それらを審議するためのWGが設置 された。これらのWGのメンバーとして，わが国からも 多くの方々の参加が要請されており，わが国への期待は 大きい。

分析手順に関するドキュメンテーションの作成という ようなことは，一見，研究活動とは縁が遠いように思わ れるかもしれないが，特に表面化学分析の分野では，た とえば，空間での電子の軌跡とか，固体と電子の相互作 用といったような基礎的な分野の理解なしには，進みえ ない分野なので，できるだけ多くの方々がこの分野に参 加していただくことを期待している。

\section{7. おわりに}

本論文では，電子分光法による表面組成の定量精度の 向上を目指したこの 15 年間の研究の進展状況を簡単に解 説した。電子分光により表面分析を行うときには，ハー ドウェアおよびソフトウェアに関する詳しい知識が要求 されるというのが現状である。しかし，はじめに述べた ように，実際の材料分析を行うユーザーにとっては，複 雑な知識を駆使して分析しなくても，一定精度の分析が できるという状態になってもらいたいものである。この ために現在, VAMAS や ISO/TC201 という, 表面分析 の標準化に関する国際共同プロジェクトが実行され，で きるだけ手法を標準化していく方向に向かいつつある。 筆者のような怠け者は，いつの日にか，自動車はまった く「メカ」を知らなくても運転できるように，表面分析 も難しい知識なしに正しいデータが取得できるように なってもらいたいと思っている。

なお，本論文では Common Data Processing System Version 3.1 のスペクトルデータベースの中で, 以下の スペクトルを使用した。No 00000104 by Iwai, No 00001016 by Fujiwara, No 00001032 by Ikeo, No 00001193 by Yoshitake, No 00001030 by Ikeo, AES_ NI (sample data), Cu_AES_1 by Goto.

\section{文献}

1) 宮崎栄三:表面科学 10, 693 (1989).
2) 徳高平蔵: ibid. 10, 703 (1989).

3) K. Yoshihara and R. Shimizu : Surf. Interface Anal. 12, 125 (1988).

4) K. Yoshihara and R. Shimizu : Surf. Interface Anal. 16, 140 (1990).

5) M. Yoshitake and K. Yoshihara : Surf. Interface Anal. 17, 711 (1991).

6) 後藤敬典, 榊原伸義, 磯兼雄一郎, 境 悠治: 真 空 35, 165 (1992).

7) K. Goto, N. Sakakibara and Y. Sakai : Microbeam Anal. 2, 123 (1993).

8) 藤田大介, 吉原一紘, 塩川善郎：表面科学 15,282 (1994).

9）表面化学分析作業部会報告「実用電子分光法講座」 (1994).

10) M.P. Seah, G. C. Smith and M.T. Anthony: Surf. Interface Anal. 15, 293 (1990).

11) 藤田大介, 吉原一紘: 表面科学 14, 429 (1993).

12) M.T. Anthony and M.P. Seah : Surf. Interface Anal. 6, 95 (1984).

13) C.J. Powell and M.P. Seah : J. Vac. Sci. Technol. A8, 735 (1990).

14) M.P. Seah and G.C. Smith : Surf. Interface Anal. 15, 751 (1990).

15) M.P. Seah and G.C. Smith : Surf. Interface Anal. 17, 855 (1990).

16) M.P. Seah : Surf. Interface Anal. 20, 243 (1990).

17) K. Yoshihara, M. Yoshitake and VAMAS-SCA Community : Surf. Interface Anal. 18, 724 (1992).

18）吉武道子, 吉原一紘, VAMAS-SCA-JAPAN: 表面 科学 15, 376 (1994).

19）たとえば，D. Briggs and M.P. Seah : "Practical Surface Analysis"(Wiley, 1990).

20) S. Tougaard: Surf. Sci. 216, 343 (1989).

21) S. Tougaard and C. Jansson: Surf. Interface Anal. 20, 1013 (1993).

22) H. Tokutaka, N. Ishihara, K. Nishimori, A. Kishida and K. Isomoto: Surf. Interface Anal. 18, 697 (1992).

23) M.P. Seah and W.A. Dench: Surf . Interface Anal. 1, 2 (1979).

24) H. Tokutaka, K. Nishimori and H. Hayashi : Surf. Sci. 149, 349 (1985).

25) S. Tanuma, C.J. Powell and D.R. Penn : Surf. Interface Anal. 11, 577 (1988).

26) S. Tanuma, C.J. Powell and D.R. Penn : Surf. Interface Anal. 21, 165 (1994).

27) S. Tanuma, T. Sekine and K. Yoshihara: Surf. Interface Anal. 15, 446 (1990).

28) W. A. Dench, L.B. Hazel and M.P. Seah : Surf. Interface Anal. 13, 63 (1988).

29) K. Yoshihara and M. Yoshitake : Surf. Interface Anal. 18, 724 (1992).

30) K. Yoshihara and M. Yoshitake: J. Vacuum Sci. Technol. A12, 2342 (1994). 